Research Article

\section{Determination of host fish suitability for unio terminalis delicatus (Bivalvia:Unionidae) from gölbaşı lake in Turkey}

\begin{abstract}
Suitable host fishes were identified for Unio terminalis delicatus (Unionidae) from Gölbaş1 lake. It was observed the glochidial infestation for the suitable host fishes in the laboratory conditional. In this study, five different fish specieses (Anguilla anguilla, Clarius gariepinus, Barbus luteus, Orechromis niloticus, Cyprinus carpio) were used as host fish in order to $U$. terminalis delicatus. It was placed in each aquarium eighteen fish and three mussels. Fishes, which are used as host were held in five aquariums of 140 liters capacity with no substrate. All the aquarium was sampled every other day for up to 45 days. The presence of glochidia in the gills and fins of the fish was studied in a stereomicroscope. The following stage, musselfish-host relationships were established. In the aquarium in which C. carpio was placed, the conglutinates were found to differ both in quantity and in structural form. Although the larvae of $U$. terminalis delicatus released successfully on three fish species: B. luteus, C. carpio and $O$. niloticus, they weren't prefer to A. Anguilla and C. gariepinus as host fish. These observations show that of three preferable host, $C$. carpio is the best option to for host fish selectivity $U$. terminalis delicatus
\end{abstract}

Key Words: Unionid, glochidia, host fish, life history, congluttinates.

\section{Introduction}

The freshwater mussels belonging to the Unionacea super family have a highly characteristic life cycle. Glochidia require a brief period as obligate ectoparasites on the gill, fins, or other external parts of fish (Haag and Warren, 2003). Glochidia spend their incubation periods in the gill of the female until mature. (Jones and Neves, 2002). The eggs cohere in groups, called conglutinates, they are released into the water in the form of packages thanks to the water outlet siphon (Kat, 1984).

If the glochidia meet a suitable host fish, they can spend several days or a few weeks on the host fish by putting themselves in the pouch. During this time, the glochidia which metamorphosed to reach the juvenile mussel stage, leave from the host fish to live benthic lifestyle (Jones and Neves, 2002). If glochidia encounter unsuitable host, they can be rejected by the fish (Zale and Neves, 1982; Haag and Warren, 1997; O'Connell and Neves, 1999). At least one species of unionid completes its glochidial metamorphosis to juveniles without a host (Lellis and King, 1998).

The diversity of host fish is quite variable among the types of mussels (Yeager and Saylor, 1995). Many mussel species use mantle tissue to facilitate transmission of glochidia to host fish (Jones and Neves, 2002). Females, during the period of glochidial release, display highly developed mantle margins which mimic small fish or large invertabrates (Barnhart and Roberts, 1997).
Hülya ŞEREFLIŞ̧AN

Faculty of Marine Sciences and Technology, Iskenderun Technical University, 31200 Iskenderun, Hatay,

Turkey

Corresponding Author

Hülya ŞEREFLİŞAN hulya.sereflisan@iste.edu.tr

Article info

Received: 14-05-2018

Accepted: 29-11-2018 DOI: $10.31797 /$ vetbio.423361

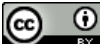

This work is licensed under a Creative Commons Attribution 4.0 International

License

Şereflişan, H. (2018). Determination of host fish suitability for unio terminalis delicatus (bivalvia:unionidae) from gölbaşı lake in Turkey. J Adv VetBio Sci Tech. 3(3): 15-22. DOI: 10.31797/vetbio.423361 
The continuity of the generation of the unionid and protection of populations is based on compatible host fish relationships (Graf, 1997). Much research has been done on Unionid species to select a suitable host fish. However, the strategy of the host fish preference and reproduction biology are still worthy of investigation.

The aim of the present study is to determine to suitable host option out of five different fish species (namely, A. anguilla, O. niloticus, C. gariepinus, $B$. luteus, $C$. carpio) for host fish selectivity from Gölbaş1 Lake, Hatay/Turkey.

\section{Methods}

\section{Study Site}

The experiment was carried out in Lake Gölbaş1, Hatay, southern Turkey, between February-April 2012 (36 30'16”N, 36²9'42”E). Lake Gölbaş1 is in the eastern Mediterranean region of Turkey, $50 \mathrm{~km}$ north of the city of Antakya ( $\left.36^{\circ} 29^{\prime} \mathrm{E}, 36^{\circ} 30^{\prime} \mathrm{N}\right)$. The lake is a natural lake with a surface area of $12 \mathrm{~km}^{2}$ at altitude of $80 \mathrm{~m}$. The lake volume is $8.000 .000 \mathrm{~m}^{3}$, with a maximum depth of $6 \mathrm{~m}$. Since it supplies water to the surrounding cotton fields, the water level is lower in spring and summer. The lake has no incoming or outgoing creeks and is only fed by spring water (Fig. $1)$.

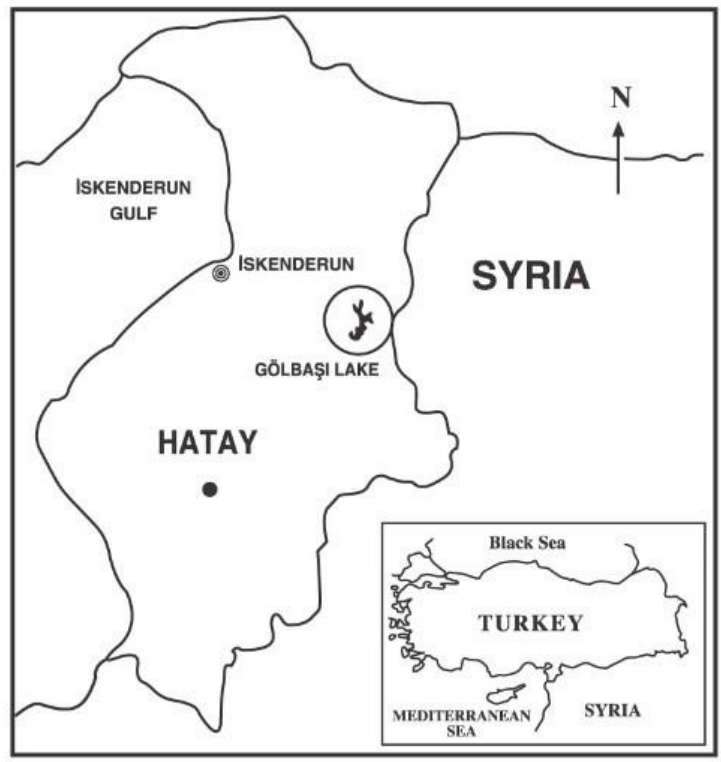

Fig 1. Map of the study side

\section{Natural host infections in laboratory}

In this study, it was used one mussel (Unio terminalis delicatus) (Fig. 2) and five fish species (A. anguilla, $C$. gariepinus, B. luteus, O. niloticus, C. carpio) (Fig. 3, 4, $5,6,7)$.

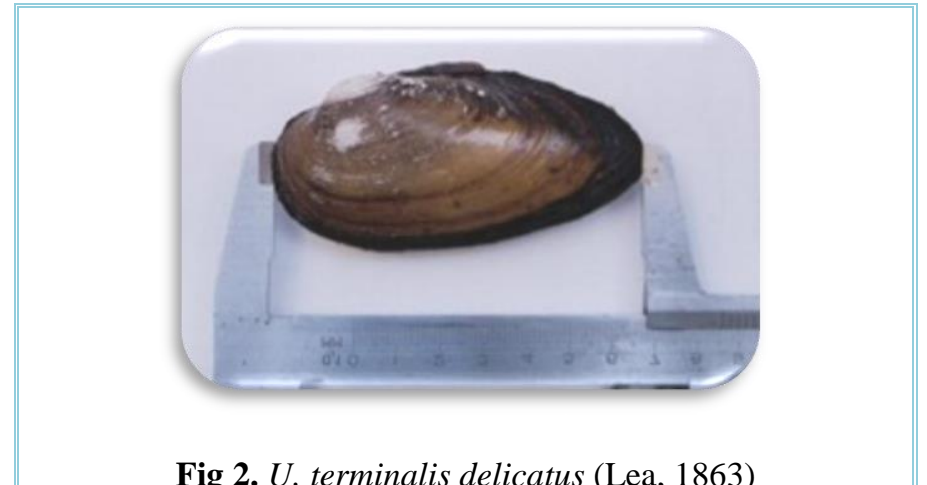

Fig 2. U. terminalis delicatus (Lea, 1863)

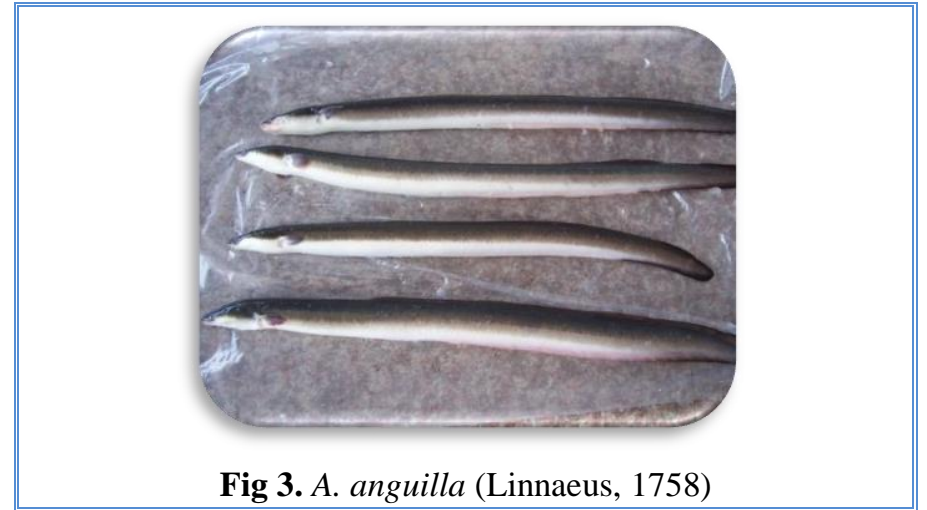

Fig 3. A. anguilla (Linnaeus, 1758)

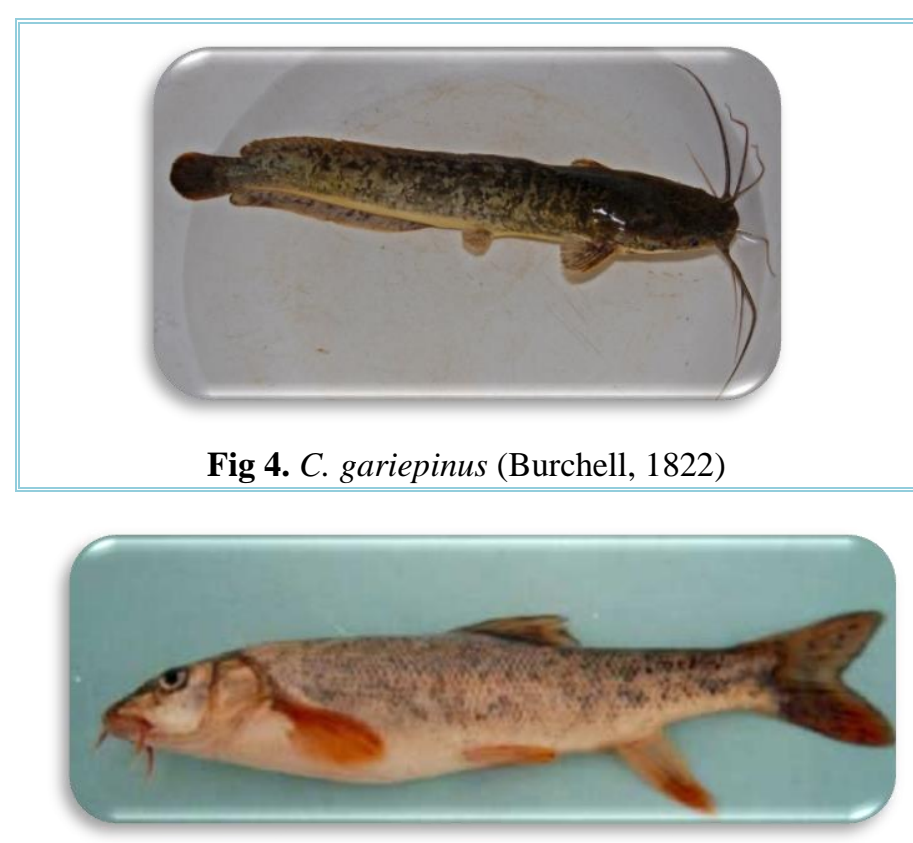

Fig 5. B. luteus (Heckel, 1843) 

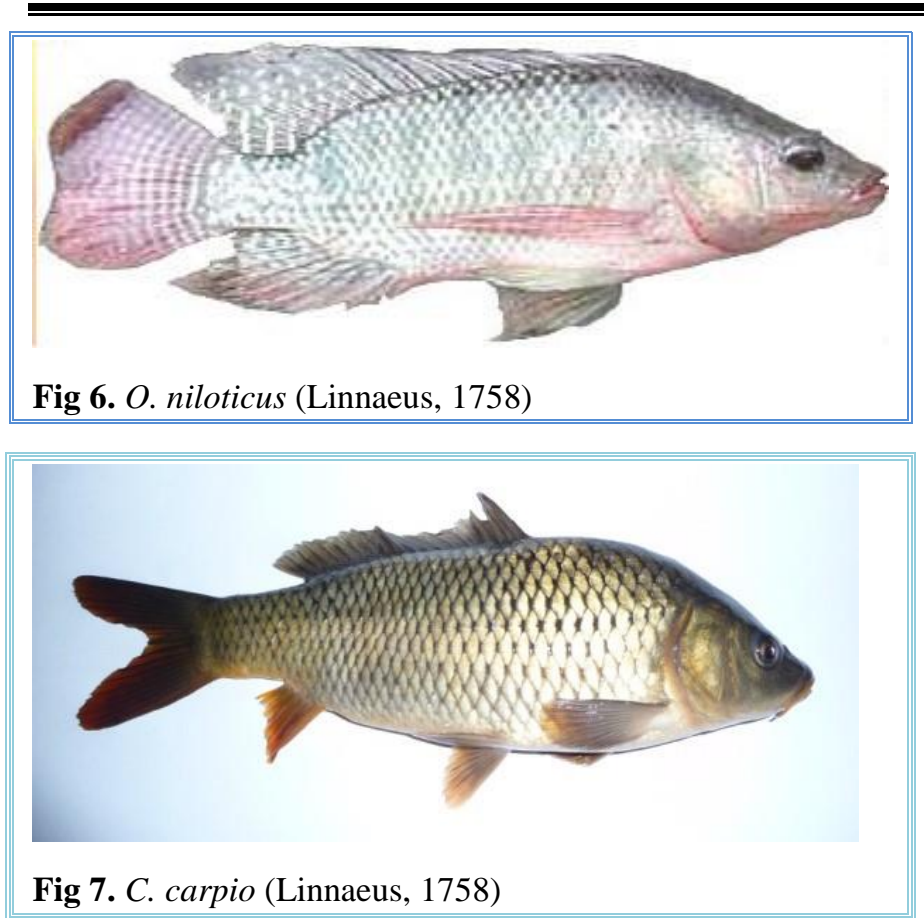

It was systematic diagnosis of the fish which were collected with set net, fyke net and long line in the lake. Two major criteria, healthy, and mature mussels, were considered to choose the specimens;

These species were collected in early February before natural infestations normally occur in the study area. Water temperature at the time of collection was 21 to $26^{\circ} \mathrm{C}$. It was assessed reproductive status of each individual by gently prying apart the valves and examining the gills. We recognized gravid females by the presence of distended gills. It was brought gravid mussels into the laboratory and placed them into aerated aquarium.

It was placed in each aquarium eighteen fish and three mussels. Fishes, which are used as host were held in five aquariums of 140 liters capacity with no substrate. All fishes were maintained in aerated aquaria in the laboratory and fed them residual fish, earthworm, and pelletized fish feed. Before the trial, all mussels were held in the same aquariums at $21-26^{\circ} \mathrm{C}$ in a few days until they well adapted in aquarium conditions. Meanwhile, mussels were fed with a suspended mixture of fito-zooplankton (Peridinium spirogyra, Pediastrum duplex, Diatomella bolfouriana, Compylodiscus clypeus, Pediastrum bonyanum, Caloneis amphisbaena, Lepadella ovalis Keratella cochlearis, Filinia erminali, Brachionus angularis,Lepadella

\section{patella, Synchaeta}

stylata,Filinia

longiseta, Chronogaster ovalis).

After the adaptation, trial aquariums were coded as aquarium A: (A. Anguilla-U. terminalis delicatus), Aquarium B: (C. gariepinus-U. terminalis delicatus), Aquarium C: (B. luteus-U. terminalis delicatus), Aquarium D: (O. niloticus-U. terminalis delicatus), Aquarium E: (C. carpio-U. terminalis delicatus). It was observed the release of the glochidia by the mussels on the gill of the fishes.

All the aquarium was sampled every other day for up to 45 days. One liter of water was siphoned from each aquarium bottom, and passed through a $120 \mu \mathrm{m}$ sieve. Debris was examined for glochidia with a light microscope Olympus CX 41 and scanning electron microscopy (SEM) Zeiss. Metamorphosed juveniles were identified by the presence of a foot, and movement (Fig. 8,9,10).

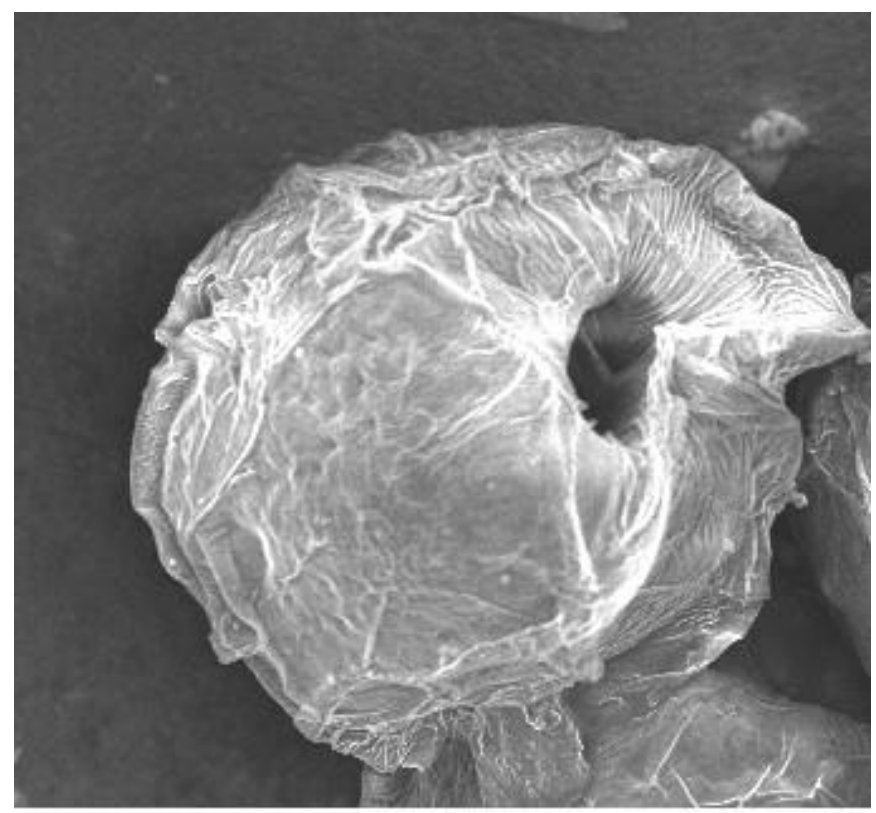

Fig 8. Scanning electron microscopy of the glochidia of $U$. terminalis delicatus in marsupium 


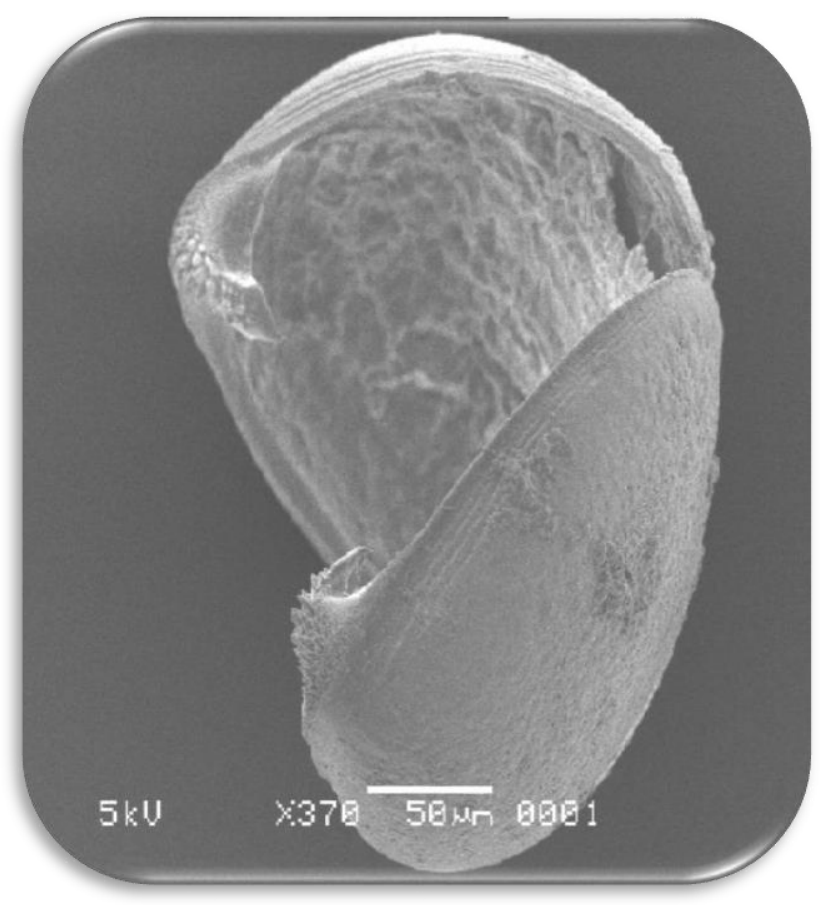

Fig 9. Scanning electron microscopy of the glochidia of $U$. terminalis delicatus in host fish gill

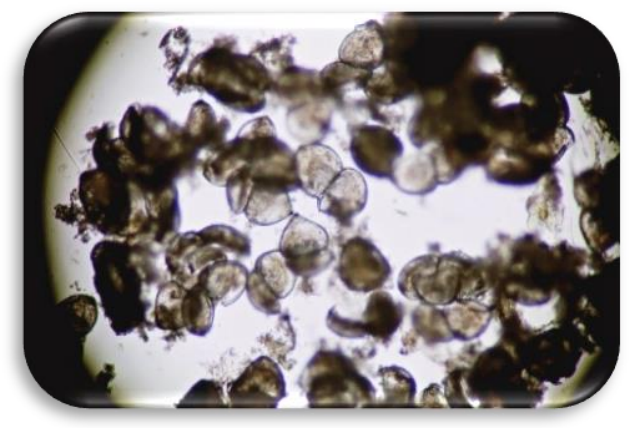

a

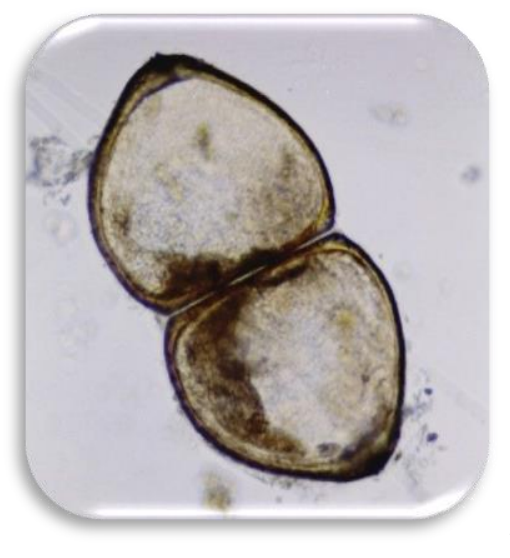

b

Fig 10. Light microscopy of the glochidia of U. terminalis delicatus a-b

\section{Results}

\section{Observation of Anguilla anguilla as host fish (aquarium A)}

It was observed that to be releasing of the glochidia by the mussels in Aquarium A at the first week of May. Some glochidia were released in small clusters. According to my observations, the mussels did not use their mantle tissue edge in order to lure fishes. Fish did not interested in glochidia packages in the bottom of the aquarium.

When A. anguilla from Aquarium a was examined by stereomicroscope, glochidia was not detected among the gill lamellae of A. anguilla (Fig. 11).

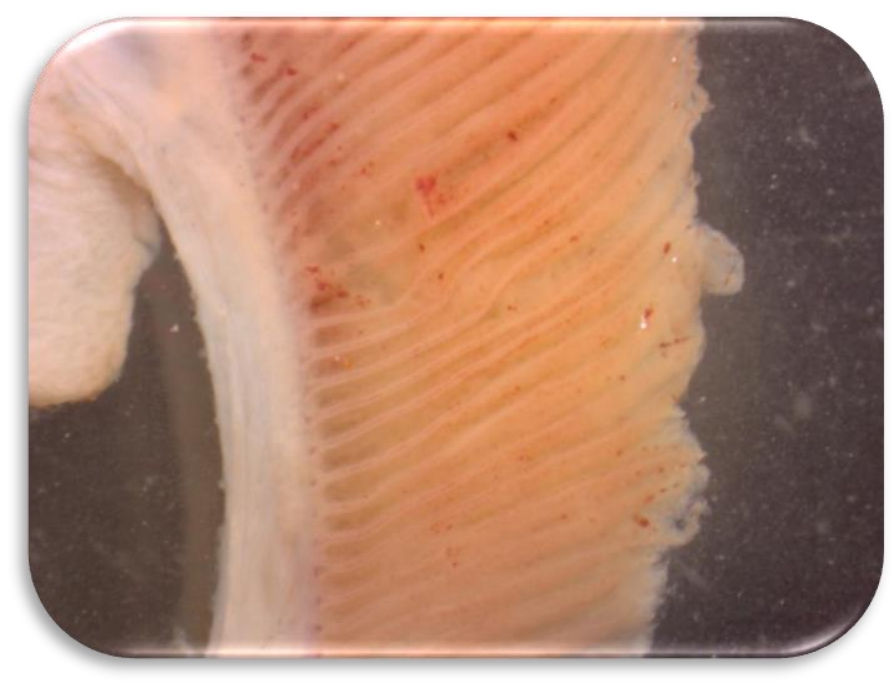

Fig 11. The image of the gill of A. Anguilla

\section{Observation of Clarius gariepinus as host fish (aquarium B)}

Glochidia release were occurred in the last days of April. Additionally, the result of glochidia realising in this aquarium was found similiar with that of $A$. Anguilla. After glochidia were released by female mussels, a large number of glochidia packets were found in the bottom of aquarium. But, when the fishes were examined under a stereo microscope, glochidia were found neither in the fins nor in the gills of the fishes. It was understood that $C$. gariepinus (Linnaeus, 1758) was not a host fish for $U$. terminalis delicatus (Fig 12.). 


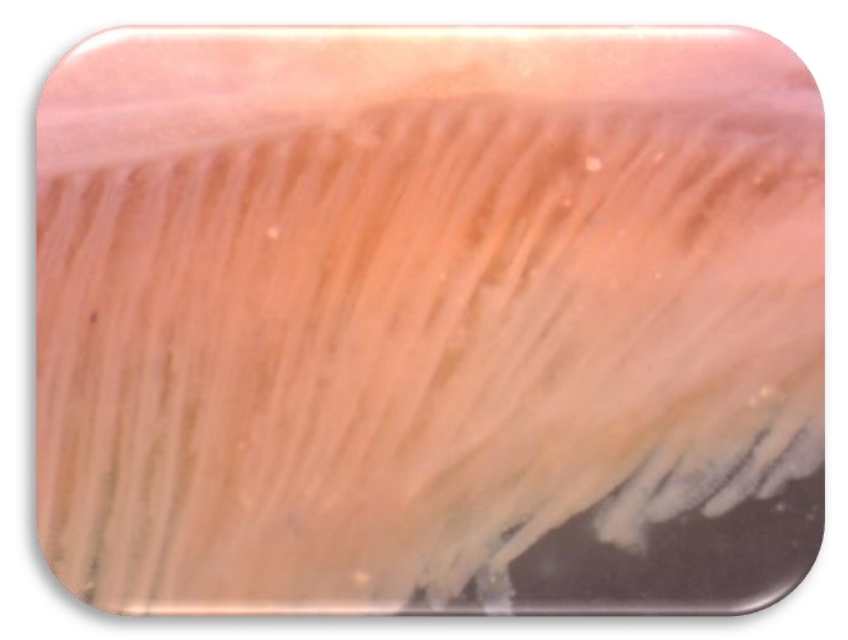

Fig 12. The image of the gill of C. Gariepinus

\section{Observation of Barbus luteus as host fish (aquarium C)}

In the first week of April, it was found many numerous conglutinates of $U$. terminalis delicatus. $U$. terminalis delicatus started to role with the mantle tissue to influence to B. luteus. It could not be determined the glochidia on the fins of these fishes which are examination under microscope. The glochidia were detected just in the gills of these fishes. It was deteminated that $B$. luteus may be use as a suitability host fish for $U$. terminalis delicatus (Fig 13a-b).

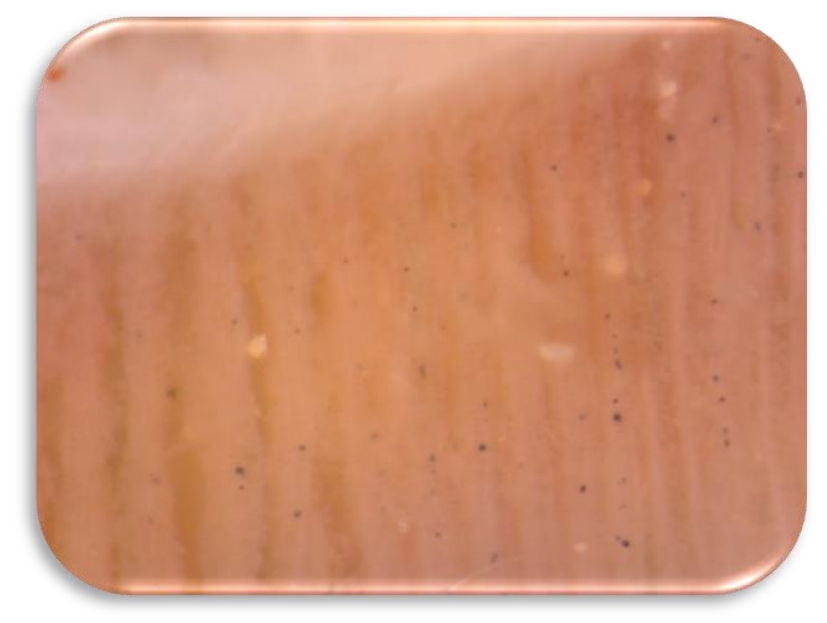

Fig 13. a-The image of the gill of B. Luteus

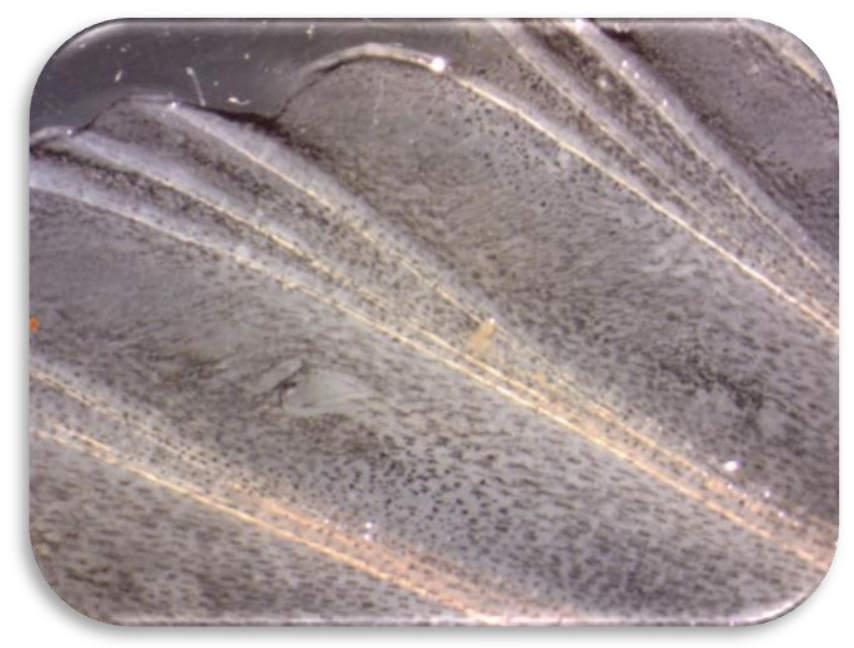

Fig 13. b- The image of the dorsal fin of B. Luteus

\section{Observation of Orechromis niloticus as host fish (aquarium D)}

Glochidia release was occurred in the first week of April. Similar result was obtained for $O$. niloticus with $B$. luteus. It could not be determined the glochidia on the fins of these fishes which are examination under microscope. It was determined to be a host fish (Fig 14a-b).

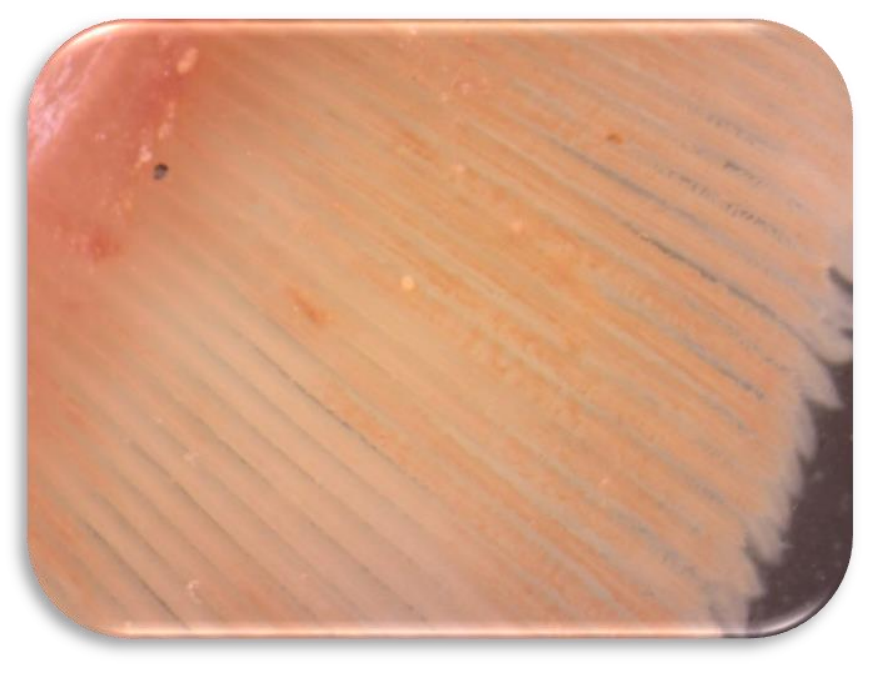

Fig 14. a-The image of the gill of $O$. Niloticus 


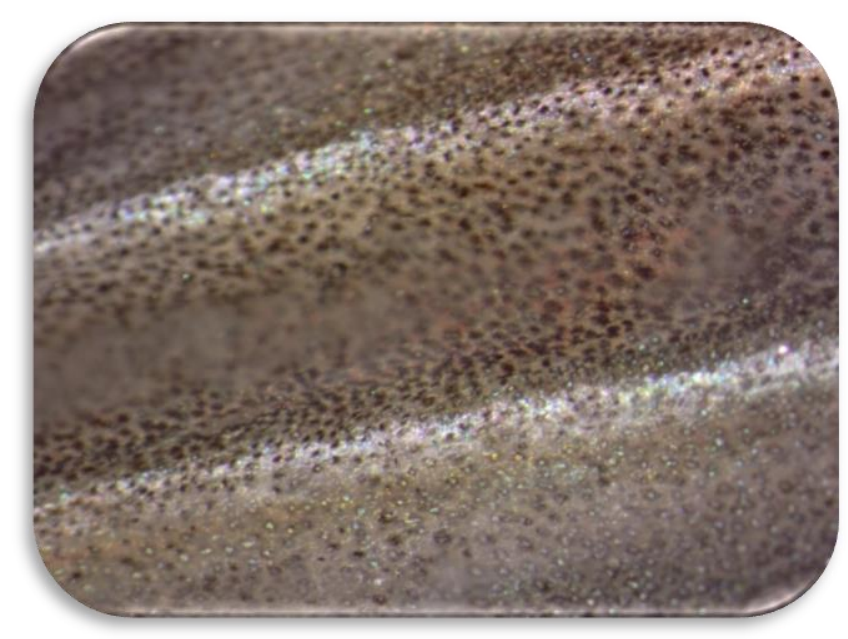

Fig 14. b- The image of the dorsal fin of $O$. Niloticus

\section{Observation of Cyprinus carpio as host fish (aquarium E)}

The water of the aquarium of $C$. carpio was different from that of all other aquariums in the terms of turbidity. Additionally, glochidia packets were observed to be scattered and deformed in the bottom of the aquarium. It was determined that $C$. carpio was the most suitability fish species as host compared to the all other four fish species studied in this present research.

When it was examined the gills of C. gariepinus under a stereomicroscope, the glochidia was detected among the gill lamellae and their fin (Fig 15 a-b).

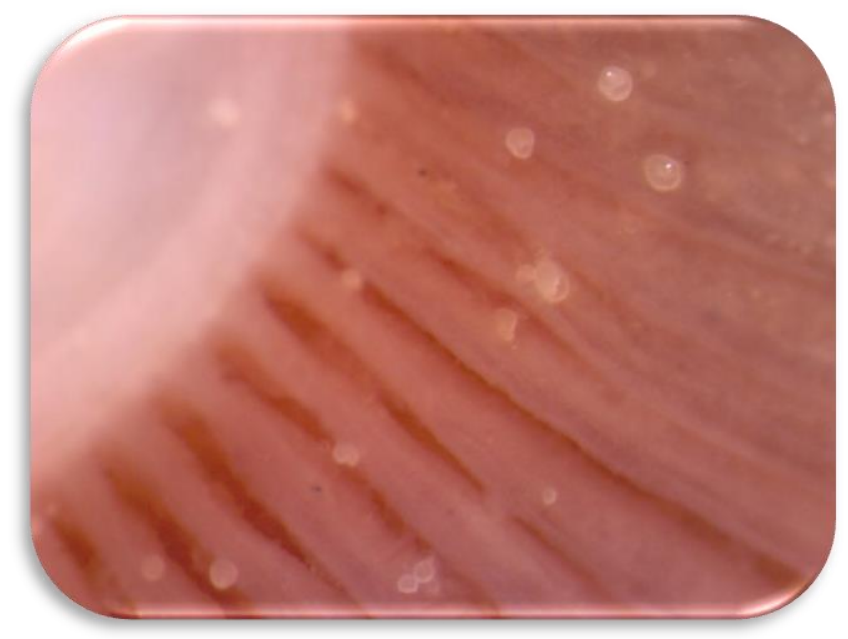

Fig 15. a-The image of the glochidia in the gill of C. Carpio

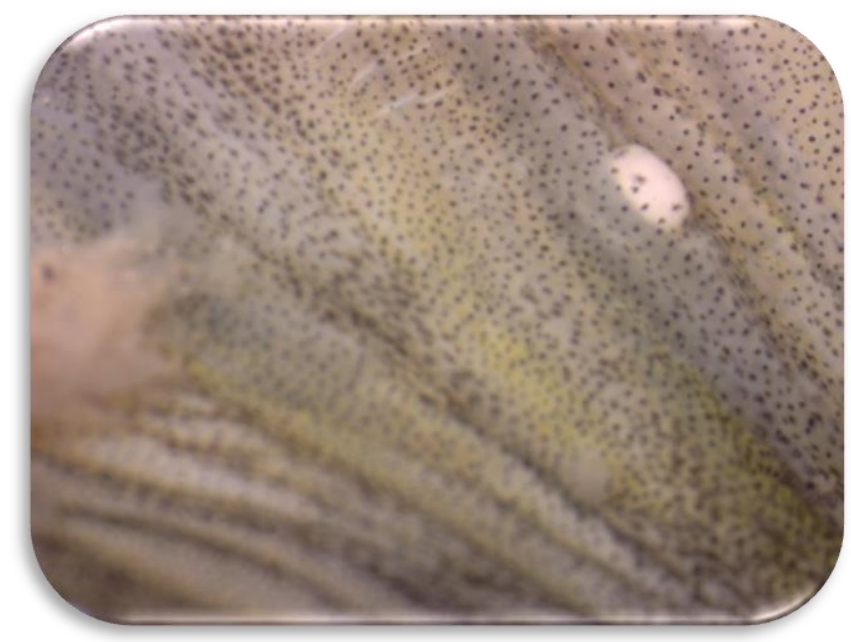

Fig 15. b- The image of the glochidia in the dorsal fin of $C$. carpio

\section{Discussion}

Gölbaşı Lake is a valuable ecological resource with its 14 fish species (Şereflişan and Şereflişan, 2001) and 7 mussels species in the region (Şereflişan, 2001). Because $U$. terminalis delicatus is the most common mussel species and has a great commercial value in the region around the Lake, many studies were carried out regarding the reproductive biology and growth performance (Çek and Şereflişan, 2006). The reproductive period and their requirement for a suitable host fish of Unio species are observed February-June and March-May, respectively (Şereflişan et al., 2009).

In this current research, a great number of the glochidia has been observed on the gill and dorsal fin of $C$. carpio in these months that previously reporting (Şereflişan et al., 2009). In some scientific research related to finding a suitable host fish pointed out that unionid species prefer cyprinidae family as hosts ( Haag et al., 1999; Haag and Warren, 2003; O'Dee and Watters, 2000). Based on the data of this study, It was concluded that $A$. anguilla and $C$. gariepinus were not accepted by $U$. terminalis delicatus as host fish.

It has been reported that the habitat is important in the relationship between mussel and host fish (Riusech and Barnhart, 2000). The habitat of $U$. terminalis delicatus which prefer slime layer is compatible with species of cyprinidae and chiclidae family (Şereflişan et al., 2004). 
Many species belonging to the Cyprinidae family have been identified as host fish for Unionids (O'Dee and Watters, 2000). Haag and Warren (2003) reported that gravid female unionids displayed mantle lures in order to attract host fish (Cyprinidae). In this study, it was observed that the unio mantle tissue was used in order to attract the fish.

It has been reported in many studies that it is very important to observe infection strategies of freshwater mussels in order to find out sutible host species (Riusech and Barnhart, 2000; Haag and Warren, 2003). In this present study, it was observed that the formand amount of glochidia packets in the aquariums. Additionaly, there were deformed glochidia packets especially in aquarium of $A$. anguilla and $C$. Gariepinus. Moreover, glochidia were out of their packets and present intensively bottom of the aquariums.

It was observed that $U$. terminalis delicatus tried to attract the fish by activating the mantle tissue during glochidia release. Although the mussel showed this behaviour for A. anguilla and C. gariepinus, it did not prefer to show to other fish. Especially, It was determinated that $\mathrm{U}$. Terminalis tend to use mantle tissuefor a long time in order to attract $C$. carpio as a suitable host. It was determined suitable hosts for delicatus during reproductive cycle under laboratory conditions. It is very important to choose the right host for Unionid in order to sustainability and Cultivation of the Unionid population.

\section{Acknowledgement}

Author's thanks to Menderes ŞEREFLIŞAN for extensive help during field works. Many thanks to Ayşe ÖZYILMAZ for the correction of the manuscript language

\section{References}

Barnhart, M.C., Roberts, A. (1997). Reproduction and fish hosts of unionids from the Ozark uplifts. p.16-20. In: K.S. Cummings, A.C. Buchanan, C.A. Mayer and T. Naimo (eds.). Conservation and management of freshwater mussels II: initiatives for the future. Proceedings of an Upper Mississippi River Conservation Committee (UMRCC) symposium, 16-18 October 1995, St. Louis, Missouri. Upper Mississippi River Conservation Committee, Rock Island, IIIinois.

Çek, Ş., Şereflişan, H. (2006). Certain reproductive characteristics of the freshwater mussel Unio terminalis delicates (Lea, 1863) in Gölbaşı Lake, Turkey. Aquaculture Research 37(13): 1305-1315.

Graf, D. L. (1997). Sympatric speciation of freshwater mussels (Bivalvia: Unionoidea): a model. American Malacological Bulletin. 14:35-40.

Haag, W.R., Warren, M. L. (1997). Host fishes and reproductive biology of 6 freshwater mussel species from the Mobile Basin, USA. Journal of the North American Benthological Society. 16:576-585.

Haag, W.R., Warren, M. L., Shilling, D. M. (1999). Host fishes and host attracting Behavior of Lampsilis altilis and Villosa vibex (Bivalvia:Unionidae). American Midland Naturalist. 141:149-157.

Haag, W. R., Warren, M. L. (2003). Host fishes and infection strategies of freshwater mussels in large Mobile Basin streams, USA. Journal of the North American Ethological Society. 22:78-91.

Jones, J. W., Neves, R. J. (2002). Life history and propogation of the endangered fanshell Pearly mussel, Cyprogenia stegaria Rafinesque (Bivalvia: Unionidae). Journal of the North American Benthological Society. 21:76-88.

Kat, P. (1984). Parasitism and the Unionicea (Bivalvia). Biological Reviews. 59:189-207.

Lellis, W. A., King, T. M. (1998). Release of metemorphosed juveniles by the green floater, Lasmigona subviridus. Triannual Unionid Report. 16:23.

O'Connell, M. T., Neves, R. J. (1999). Evidence of immunological responses by a host fish (Ambloplites rupestris) and two non-host fishes (Cyprinus carpio and Carassius auratus) to glochidia of a freshwater mussel (Villosa iris). Journal of Freshwater Ecology. 14:71-78.

O'Dee, S. H., Watters, G. T. (2000). New or confirmed host identifications for ten freshwater mussels. pp. 7782. Proceedings of the Conservation, Captive Care, and Propagation of Freshwater Mussels Symposium.

Şereflişan, H., Şereflişan, M., Akyurt, İ. (2004). Gölbaşı Gölünde Bulunan Tatlı $\mathrm{Su}$ Midyelerinin Substrat ve Derinlik Bakımından Mevsimsel Olarak Yer Değişimi. Turkish Journal of Aquatic Life. 2:133-140 
Şereflişan, H., Çek, Ş., Şereflişan, M. (2009). Histological studies on gametogenesis, hermaphroditism and the gametogenic cycle of Anodonta gabillotia pseudodopsis (Locard, 1883) in the Lake Gölbaşi, Turkey (Bivalvia: Unionidae). Journal of Shellfish Research. 28:337-344.

Şereflişan, H. (2001). Kırıkhan Gölbası Gölü (HATAY) Çift Kabuklu (Bivalvia) Türleri.. XI. Ulusal Su Ürünleri Sempozyumu (Tam Metin Bildiri) (Yayın No:1319051).

Şereflişan, M., Şereflişan, H. (2001). Kırıkhan Gölbası Gölü (Hatay) Balık Faunası XI. Ulusal Su Ürünleri Sempozyumu. (Tam Metin Bildiri/)(Yayın No:1319029).

Riusech, F. A., Barnhart, M. C. (2000). Host suitability and utilization in Venustachoncha ellipsiformis and Venustaconcha pleasii (Bivalvia, Unionidae) from the Ozark Plateaus. pp 43-61 in T.A. Tankersley, T. Watters, B. Armitage, and D. Warmolts (editors). Proceedings of the Conservation, Captive Care, and Propagation of Freshwater Mussels Symposium, 6-8 March 1998, Columbus, Ohio. Ohio University Press, Columbus, Ohio.

Yeager, B. L., Saylor, C. F. (1995). Fish hosts for four species of freshwater mussels (Pelecypoda: Unionidae) in the upper Tennessee River drainage. American Midland Naturalist Journal. 133:1-6.

Zale, A. V., Neves, R. J. (1982). Fish hosts of four species of mussels (Mollusca: Unionidae) in Big Moccasin. Creek, Virginia. Canadian Journal of Zoology 69:25352542. 